\title{
Ticagrelor and Acetylsalicylic Acid after Placement of Pipeline Embolization Device for Cerebral Aneurysm: A Case Series
}

\author{
Jodi R DeGrote, Elizabeth M Olafson, Alexander Drofa, Evgueni Kouznetzov, Michael Manchak, \\ Nathan D Leedahl, and David D Leedahl
}

\begin{abstract}
Background: Dual antiplatelet therapy with acetylsalicylic acid (ASA) and a P2Y12-receptor antagonist is often used to prevent thrombotic complications after placement of a Pipeline embolization device (PED) for cerebral aneurysm. Although clopidogrel is common in this setting, high rates of nonresponse to this drug have made ticagrelor a potentially attractive alternative.
\end{abstract}

Objective: To describe safety and efficacy outcomes for ticagrelor following PED placement, including measurement of platelet function.

Methods: A retrospective analysis of data was completed for patients who underwent PED placement for cerebral aneurysm at a single centre between November 2015 and March 2017, with subsequent prescription of ticagrelor and ASA as dual antiplatelet therapy. The primary end point was any ischemic stroke or death within 1 year after the procedure. Intracranial hemorrhage was a secondary end point. Additionally, measurement of and values for platelet reactivity units (PRUs) during receipt of ticagrelor and ASA were evaluated.

Results: A total of 29 patients were included in this retrospective study. One patient experienced ischemic stroke 226 days after placement of the PED. In addition, 3 patients died during the 1 -year follow-up period for causes unrelated to stroke or bleeding complications. No cases of intracranial hemorrhage were observed. Samples for measurement of P2Y12 levels were drawn at the discretion of the neurointerventionalists, and the PRU value was measured at least once for 28 (97\%) of the 29 patients. The mean number of PRU measurements per patient after initiation of ticagrelor was 2.1 (standard deviation [SD] 1). Mean PRU value after initiation of ticagrelor was 65 (SD 57).

Conclusions: In this case series describing the use of ticagrelor and ASA as dual antiplatelet therapy after PED placement for cerebral aneurysm, there was just one ischemic stroke, which occurred after the dual antiplatelet therapy had been discontinued. Further prospective trials are needed to describe the utility of ticagrelor use after PED placement, as well as its dosing and monitoring.

\section{RÉSUMÉ}

Contexte : Une bithérapie antiplaquettaire composée d'acide acétylsalicylique (AAS) et d'un inhibiteur du récepteur P2Y12 est fréquemment utilisée pour prévenir les complications thrombotiques après la mise en place d'un dispositif d'embolisation Pipeline pour traiter un anévrisme cérébral. Quoique le clopidogrel soit souvent utilisé dans ce contexte, des taux élevés d'absence de réponse à ce médicament ont fait du ticagrélor une solution de rechange potentiellement intéressante.

Objectif : Décrire les résultats relatifs à la sécurité et à l'efficacité du ticagrélor après la mise en place d'un dispositif d'embolisation, y compris l'analyse de la fonction plaquettaire.

Méthodes : Une analyse rétrospective de données a été réalisée dans un seul centre entre novembre 2015 et mars 2017 à l'aide des dossiers médicaux de patients chez qui a été posé un dispositif d'embolisation Pipeline comme traitement pour un anévrisme cérébral et à qui a ensuite été prescrite une bithérapie antiplaquettaire de ticagrélor et d'AAS. Le critère d'évaluation principal était les cas d'infarctus cérébral ou de décès durant l'année suivant l'opération. Les cas d'hémorragie intracrânienne ont servi de critère d'évaluation secondaire. De plus, l'analyse a porté sur l'évaluation de la réactivité plaquettaire et sa quantification en unités de réaction au P2Y12 pendant la prise de ticagrélor et d'AAS.

Résultats : Au total, 29 patients ont été admis à la présente étude rétrospective. Un patient a subi un infarctus cérébral 226 jours après la mise en place d'un dispositif d'embolisation Pipeline. De plus, 3 patients sont décédés au cours de la période de suivi d'un an en raison de causes sans lien avec des complications liées à un accident vasculaire cérébral ou à une hémorragie. Aucun cas d'hémorragie intracrânienne n'a été observé. Les échantillons destinés à la mesure des unités de réaction au P2Y12 ont été prélevés selon le jugement des neuro-intervenants et l'évaluation de la réactivité plaquettaire a été réalisée au moins une fois chez 28 (97\%) des 29 patients. Le nombre moyen de mesures des unités de réaction au P2Y12 par patient était de 2,1 (écart-type de 1). Après l'amorce d'un traitement par ticagrélor, le résultat moyen en unités de réaction au P2Y12 était de 65 (écart-type de 57).

Conclusions : Dans la présente série de cas décrivant l'utilisation d'une bithérapie antiplaquettaire composée de ticagrélor et d'AAS après la mise en place d'un dispositif d'embolisation Pipeline comme traitement pour 
Keywords: ticagrelor, antiplatelet agent, neurointervention, Pipeline embolization device, flow diversion, dual antiplatelet therapy

Can J Hosp Pharm. 2018;71(6):349-55 un anévrisme cérébral, seul un cas d'infarctus cérébral a été observé et il s'est produit après l'arrêt de la bithérapie antiplaquettaire. De plus amples études prospectives sont nécessaires pour décrire l'utilité et la posologie du ticagrélor ainsi que le suivi du traitement après la mise en place d'un dispositif d'embolisation Pipeline.

Mots clés : ticagrélor, antiplaquettaire, intervention neurologique, dispositif d'embolisation Pipeline, dérivation de flux, bithérapie antiplaquettaire

\section{INTRODUCTION}

$\mathrm{T}_{\mathrm{s}}^{\mathrm{h}}$ Pe Pipeline embolization device (PED) (Medtronic, Minneapolis, Minnesota) is a flow diverter stent, which has offered substantial improvement in the management of complex aneurysms relative to conventional microsurgical and endovascular therapies. Flow diversion enhances aneurysmal occlusion and is associated with a lower rate of retreatment. ${ }^{1}$ The benefits of this new type of stent are counterbalanced by the potential for severe thrombotic complications due to the increase in percentage of metal surface area. The decreased porosity of this flow diverter stent results in greater than $30 \%$ metal surface area (compared with $<10 \%$ for traditional intracranial stents) and may be responsible for the increased risk of in-stent thrombosis. ${ }^{1}$

Although the standard of care for patients receiving cardiac stents includes dual antiplatelet therapy, the best approach to antiplatelet therapy in the setting of neurovascular procedures remains unknown. ${ }^{2}$ The combination of ticagrelor and acetylsalicylic acid (ASA) appears to be a safe and efficacious alternative to clopidogrel and ASA, most recently described by Moore and others. ${ }^{3}$ To add to the growing body of knowledge in this area, we sought to complete a large case series, with 1-year follow-up, to describe ticagrelor use after PED placement for treatment of cerebral aneurysm. The objective was to describe safety and efficacy outcomes, including ischemic stroke, death, and intracranial hemorrhage. In addition, we described the measurement of and results for platelet reactivity units (PRUs) while patients were receiving ticagrelor and ASA.

\section{METHODS}

This retrospective, single-centre study was conducted at a 583-bed acute care facility located in North Dakota, USA, and included patients who received oral ticagrelor and ASA after PED placement in the setting of ruptured or unruptured cerebral aneurysm (November 2015 through March 2017). Patients were excluded if they had also received stent-assisted coiling or were less than 18 years of age. The investigation was approved by the Sanford Medical Center institutional review board, with a waiver of informed consent, and was performed in accordance with the ethical standards of the 1964 Declaration of Helsinki and its later amendments.

Potentially eligible patients were identified by querying the neurointerventional stent registry with the search terms "ticagrelor" and "Pipeline embolization device"; inclusion was validated by checking the ticagrelor prescription registry in the pharmacy department. The type of neurointerventional procedure and the administration of ticagrelor and ASA as dual antiplatelet therapy were confirmed using patient information collected via manual abstraction from the institution's medical records by 2 reviewers (J.R.D., E.M.O.).

Each PED had been placed by 1 of 2 neurointerventionalists (A.D., E.K.) at the institution, each of whom had endovascular neurosurgery fellowship training. The devices were placed in accordance with usual procedures, as outlined in neurointerventional radiology checklists. Given unpredictable platelet inhibition with clopidogrel, ${ }^{4-6}$ ticagrelor (in combination with ASA) was the standard antiplatelet treatment at this institution. Patients who underwent elective PED placement generally received 5 days of combination therapy before the procedure, consisting of ticagrelor $90 \mathrm{mg}$ twice daily and ASA $81 \mathrm{mg}$ daily, followed by ticagrelor $90 \mathrm{mg}$ twice daily and ASA $81 \mathrm{mg}$ daily after the procedure. If stent placement was unplanned, single loading doses of ticagrelor $180 \mathrm{mg}$ and ASA $325 \mathrm{mg}$ were administered at the time of the procedure, followed by ticagrelor $90 \mathrm{mg}$ twice daily and ASA $81 \mathrm{mg}$ daily. Dual antiplatelet therapy with ticagrelor and ASA was continued until a follow-up appointment at 6 months after the intervention, when angiography was performed. If no complications (e.g., continued aneurysm filling or incomplete endothelialization) were identified, the ticagrelor was generally discontinued at that time.

The efficacy of antiplatelet therapy was assessed with the VerifyNow platelet inhibition assay (VerifyNow, San Diego, California). This assay was most commonly performed at 2 or 3 time points: $1-8 \mathrm{~h}$ after the $180-\mathrm{mg}$ ticagrelor loading dose (for patients who received a loading dose), at the 6-month follow-up appointment, and at other times at the discretion of 
the neurointerventionalist. If the PRU value measured at any of these time points was less than 70 and/or the patient was not appropriately tolerating dual antiplatelet therapy (as indicated by minor bleeding or other complications), the neurointerventionalist had the option to reduce the ticagrelor dosage to $60 \mathrm{mg}$ twice daily. ${ }^{7}$

Demographic characteristics (age, sex, nature of procedure [elective or unplanned], size of aneurysm, location of aneurysm, number of stents placed, previous subarachnoid hemorrhage, smoking history) and results of platelet inhibition assays (measured in terms of PRUs) were collected for each patient.

The outcomes evaluated were ischemic stroke or death within 1 year after the procedure. Intracranial hemorrhage was a secondary end point. Ischemic stroke was defined as a documented focal neurological deficit, demonstrated by results of follow-up magnetic resonance imaging (MRI) that differed from imaging results before PED placement and associated with a change greater than 4 in scoring with the National Institutes of Health Stroke Scale that lasted for at least $24 \mathrm{~h}$ and was not attributable to delirium or encephalopathy. ${ }^{8}$ Cerebral hemorrhagic complications were defined as new bleeding detected by computed tomography or MRI according to the same National Institutes of Health Stroke Scale score and time thresholds as the definition of ischemic stroke. ${ }^{8}$ Two reviewers (J.R.D., E.M.O.) manually evaluated patients' electronic charts for documented complications. In addition, electronic medical records (EMRs) were queried with an electronic search function for the following keywords, to ensure full capture of data for stroke: "thrombus", "stroke", "infarct", "hemorrhagic", "hemorrhage", "bleed", and "blood".

Demographic data and results were analyzed using Microsoft Office Excel 2016 (Microsoft Corporation, Redmond, Washington), and descriptive statistics are reported here.

\section{RESULTS}

Between November 30, 2015, and March 20, 2017, a total of 34 patients met the initial inclusion criteria. Of these, 5 patients were excluded because they had undergone concomitant stentassisted coiling, leaving a final sample of 29 patients. Of these patients, $10(34 \%)$ were men, and the overall mean age was 61 years. Nine $(31 \%)$ of the patients had a history of subarachnoid hemorrhage, and 19 (66\%) had a history of smoking or were current smokers (Table 1).

All of the patients had undergone intracranial PED placement, and 18 (62\%) of the procedures had been elective. For 25 of the 29 patients, 1 PED was placed, and for 4 patients, 2 PEDs were placed. The aneurysm size and location for each patient is described in Table 2.

One of the patients experienced an ischemic event during the 1-year follow-up period (Table 3). This event occurred on post-procedure day 226, after discontinuation of the dual

\section{Table 1. Demographic Characteristics of Patients Receiving Ticagrelor and ASA for PED}

\begin{tabular}{|c|c|}
\hline Characteristic & $\begin{array}{c}\text { No. (\%) of Patients* } \\
(n=29)\end{array}$ \\
\hline$\overline{\text { Age, years (mean } \pm \text { SD) }}$ & $61 \pm 13$ \\
\hline Sex, male & $10(34)$ \\
\hline Elective procedure & $18(62)$ \\
\hline History of SAH & $9(31)$ \\
\hline Smoker & $19(66)$ \\
\hline \multicolumn{2}{|l|}{ No. of PEDs placed } \\
\hline 1 & $25(86)$ \\
\hline 2 & $4(14)$ \\
\hline
\end{tabular}

antiplatelet therapy. More specifically, the ticagrelor had been stopped 196 days after PED placement, with continuation of ASA $81 \mathrm{mg}$ daily; the patient confirmed adherence with the ASA therapy. In this patient, a single PED had been placed in the right internal carotid artery. MRI after the ischemic event showed complete occlusion of this artery, which resulted in small watershed infarcts in the right hemisphere.

Three of the patients died (on post-procedure days 50, 70, and 313 , respectively) for causes unrelated to neurologic or bleeding complication, specifically discontinuation of hemodialysis (with shift to palliative care), an unknown cause, and septic shock in an immunocompromised patient.

Overall, the patients continued ticagrelor therapy for a median of 196 days (interquartile range 184-215). The calculation of median ticagrelor duration was based on data for 27 of the 29 patients; for the other 2 patients, the discontinuation date could not be determined by chart review.

Samples for measurement of P2Y12 level were drawn at the discretion of the neurointerventionalists, and 28 (97\%) of the 29 patients underwent at least one PRU measurement. The mean number of PRU measurements per patient was 2.1 (standard deviation $[\mathrm{SD}] 1$ ). Among PRU values determined after initiation of ticagrelor, the mean was 65 (SD 57). Of the 28 patients for whom PRU level was measured, 21 had at least 1 PRU value less than 70 . For 11 of the patients, the dosage of ticagrelor was reduced to $60 \mathrm{mg}$ twice daily sometime during their therapy.

\section{DISCUSSION}

To the authors' knowledge, this is the largest case series, with the longest duration of follow-up, describing patients who received ticagrelor and ASA in the setting of PED placement for cerebral aneurysm. In this cohort of 29 patients, 1 patient experienced an ischemic event during the 12-month follow-up (after completing 6 months of post-procedure dual antiplatelet therapy). No cases of intracranial hemorrhage were observed. 
Table 2 (Part 1 of 2). Detailed Information for Patients Receiving Ticagrelor and ASA for PED

\begin{tabular}{|c|c|c|c|c|c|c|c|}
\hline Patient No. & Aneurysm Size & $\begin{array}{l}\text { Location of } \\
\text { Aneurysm }\end{array}$ & $\begin{array}{l}\text { No. of PEDs } \\
\text { Placed }\end{array}$ & $\begin{array}{l}\text { Hemorrhagic } \\
\text { or } \\
\text { Thrombotic } \\
\text { Complications }\end{array}$ & Death & $\begin{array}{l}\text { PRU Value(s) } \\
\text { Associated } \\
\text { with } \\
\text { Ticagrelor } \\
\text { Administration }\end{array}$ & $\begin{array}{c}\text { Ticagrelor } \\
\text { Dosage } \\
\text { Reduced } \\
\text { to } \\
60 \mathrm{mg} \text { BID }\end{array}$ \\
\hline 1 & $\begin{array}{l}6.5 \times 4.6 \times 4.2 \mathrm{~mm} \text {, } \\
\text { with 3.93-mm neck }\end{array}$ & $\begin{array}{l}\text { Left superior } \\
\text { hypophyseal artery }\end{array}$ & 1 & None & $\begin{array}{l}\text { Yes (time from } \\
\text { procedure to } \\
\text { death } 70 \text { days) }\end{array}$ & 189 & No \\
\hline 2 & $6 \mathrm{~mm}$ & $\begin{array}{l}\text { Anterior } \\
\text { communicating } \\
\text { artery }\end{array}$ & 1 & None & No & $9,50,7$ & No \\
\hline 3 & $\begin{array}{l}8 \times 5 \times 5 \mathrm{~mm} \text { with } \\
6 \text {-mm neck }\end{array}$ & Right vertebral artery & 1 & None & No & $85,59,91,6$ & No \\
\hline 4 & $\begin{array}{l}3.1 \mathrm{~cm} \text { transverse } \\
\times 2.8 \mathrm{~cm}\end{array}$ & Basilar artery & 1 & None & $\begin{array}{l}\text { Yes (time from } \\
\text { procedure to } \\
\text { death } 50 \text { days) }\end{array}$ & 160 & No \\
\hline 5 & $\begin{array}{l}\text { 7.5-mm cavernous } \\
\text { aneurysm and } \\
1.3 \times 3 \text { mm blister- } \\
\text { type aneurysm }\end{array}$ & $\begin{array}{l}\text { Right internal } \\
\text { carotid artery }\end{array}$ & 2 & None & No & $9,16,6$ & Yes \\
\hline 6 & $\begin{array}{l}\text { 9.5-mm fusiform } \\
\text { aneurysm of carotid } \\
\text { terminus, } 4.1-\mathrm{mm} \\
\text { fusiform aneurysm } \\
\text { of the M1 segment }\end{array}$ & $\begin{array}{l}\text { Left middle cerebral } \\
\text { artery and terminus } \\
\text { of left internal } \\
\text { carotid artery }\end{array}$ & 2 & None & $\begin{array}{l}\text { Yes (time from } \\
\text { procedure to } \\
\text { death } 313 \text { days) }\end{array}$ & 118,91 & No \\
\hline 7 & $6 \mathrm{~mm}$ & $\begin{array}{l}\text { Right posterior } \\
\text { communicating } \\
\text { artery }\end{array}$ & 1 & None & No & 4,8 & Yes \\
\hline 8 & $\begin{array}{l}2.87 \times 1.7 \mathrm{~mm} \\
\text { blister type }\end{array}$ & $\begin{array}{l}\text { Left internal carotid } \\
\text { artery }\end{array}$ & 1 & None & No & $235,183,69$ & Yes \\
\hline$\overline{9}$ & $7 \mathrm{~mm} \times 10 \mathrm{~mm}$ & Right vertebral artery & 1 & None & No & 31,74 & No \\
\hline 10 & $\begin{array}{l}\text { Previously treated } \\
\text { aneurysm with } \\
\text { increased filling of } \\
\text { coil mass }\end{array}$ & $\begin{array}{l}\text { Right superior } \\
\text { cerebellar artery }\end{array}$ & 1 & None & No & $185,77,61$ & No \\
\hline$\overline{11}$ & $5 \mathrm{~mm}$ & $\begin{array}{l}\text { Anterior } \\
\text { communicating } \\
\text { artery }\end{array}$ & 1 & None & No & $54,14,43$ & Yes \\
\hline$\overline{12}$ & $5.5 \mathrm{~mm}$ & $\begin{array}{l}\text { Right internal } \\
\text { carotid artery, } \\
\text { cavernous }\end{array}$ & 1 & $\begin{array}{l}\text { No hemorrhagic } \\
\text { complications; } \\
\text { one thrombotic } \\
\text { complication } \\
\text { (time from } \\
\text { procedure to } \\
\text { event } 226 \text { days) }\end{array}$ & No & 7,8 & Yes \\
\hline$\overline{13}$ & $2 \mathrm{~mm}$ & $\begin{array}{l}\text { Left internal carotid } \\
\text { artery }\end{array}$ & 1 & None & No & 80,41 & No \\
\hline$\overline{14}$ & $\begin{array}{l}\text { Previously treated } \\
\text { aneurysm with } \\
\text { recurrence }\end{array}$ & $\begin{array}{l}\text { Left internal carotid } \\
\text { artery }\end{array}$ & 1 & None & No & 108,19 & No \\
\hline$\overline{15}$ & $\begin{array}{l}\text { 14-mm aneurysm } \\
\text { projecting from } \\
\text { ophthalmic segment } \\
\text { of right internal } \\
\text { carotid artery; } \\
\text { 1.6-mm carotid } \\
\text { cave aneurysm; } \\
\text { 2.1-mm dorsal } \\
\text { wall blister aneurysm }\end{array}$ & $\begin{array}{l}\text { Right internal } \\
\text { carotid artery } \\
\text { (multiple aneurysms) }\end{array}$ & 2 & None & No & 68 & No \\
\hline$\overline{16}$ & $\begin{array}{l}3.3 \times 3 \mathrm{~mm} \text {, } \\
\text { with } 2.4-\mathrm{mm} \text { neck }\end{array}$ & $\begin{array}{l}\text { Left ophthalmic } \\
\text { artery }\end{array}$ & 1 & None & No & 83,52 & No \\
\hline$\overline{17}$ & $\begin{array}{l}2.2 \mathrm{~mm} \text {, with } \\
1.9-\mathrm{mm} \text { neck }\end{array}$ & $\begin{array}{l}\text { Left internal carotid } \\
\text { artery }\end{array}$ & 1 & None & No & $71,47,75$ & Yes \\
\hline
\end{tabular}


Table 2 (Part 2 of 2). Detailed Information for Patients Receiving Ticagrelor and ASA for PED

\begin{tabular}{|c|c|c|c|c|c|c|c|}
\hline Patient No. & Aneurysm Size & $\begin{array}{l}\text { Location of } \\
\text { Aneurysm }\end{array}$ & $\begin{array}{l}\text { No. of PEDs } \\
\text { Placed }\end{array}$ & $\begin{array}{c}\text { Hemorrhagic } \\
\text { or } \\
\text { Thrombotic } \\
\text { Complications }\end{array}$ & Death & $\begin{array}{l}\text { PRU Value(s) } \\
\text { Associated } \\
\text { with } \\
\text { Ticagrelor } \\
\text { Administration }\end{array}$ & $\begin{array}{c}\text { Ticagrelor } \\
\text { Dosage } \\
\text { Reduced } \\
\text { to } \\
60 \mathrm{mg} \text { BID }\end{array}$ \\
\hline 18 & $7.7 \times 9.1 \mathrm{~mm}$ & $\begin{array}{l}\text { Left internal carotid } \\
\text { artery }\end{array}$ & 1 & None & No & $158,110,138$ & Yes \\
\hline 19 & $7.9 \mathrm{~mm}$ & $\begin{array}{l}\text { Left internal carotid } \\
\text { artery }\end{array}$ & 1 & None & No & $15,15,24,10$ & No \\
\hline 20 & $\begin{array}{l}\text { 2.2-mm bilobular } \\
\text { aneurysm }\end{array}$ & $\begin{array}{l}\text { Left internal carotid } \\
\text { artery }\end{array}$ & 1 & None & No & 205,20 & No \\
\hline 21 & $4 \mathrm{~mm}$ & $\begin{array}{l}\text { Right ophthalmic } \\
\text { artery }\end{array}$ & 1 & None & No & 79,23 & Yes \\
\hline 22 & $\begin{array}{l}6.7 \times 11 \mathrm{~mm} \\
\text { cavernous aneurysm, } \\
\text { with 7-mm neck }\end{array}$ & $\begin{array}{l}\text { Right internal } \\
\text { carotid artery }\end{array}$ & 1 & None & No & 124 & No \\
\hline 23 & $\begin{array}{l}8 \mathrm{~mm} \text {, with } \\
\text { 3.8-mm neck }\end{array}$ & $\begin{array}{l}\text { Anterior } \\
\text { communicating } \\
\text { artery }\end{array}$ & 2 & None & No & 79,93 & No \\
\hline 24 & $11 \mathrm{~mm}$ & Basilar artery & 1 & None & No & 6,28 & No \\
\hline 25 & $6 \mathrm{~mm}$ & $\begin{array}{l}\text { Posterior } \\
\text { communicating } \\
\text { artery }\end{array}$ & 1 & None & No & 7,8 & Yes \\
\hline 26 & $6 \times 4 \mathrm{~mm}$ & Right vertebral artery & 1 & None & No & $\begin{array}{l}\text { No PRU values } \\
\text { obtained }\end{array}$ & No \\
\hline 27 & Wide neck (4.3 mm) & $\begin{array}{l}\text { Left ventricular } \\
\text { artery; across left } \\
\text { posterior inferior } \\
\text { cerebellar artery }\end{array}$ & 1 & None & No & 4 & No \\
\hline 28 & $1.5 \mathrm{~mm}$ & $\begin{array}{l}\text { Right internal } \\
\text { carotid artery } \\
\text { (blister type) }\end{array}$ & 1 & None & No & 20 & Yes \\
\hline 29 & $3.8 \mathrm{~mm}$ & $\begin{array}{l}\text { Right ophthalmic } \\
\text { artery }\end{array}$ & 1 & None & No & 73 & Yes \\
\hline
\end{tabular}

$\overline{\mathrm{ASA}}=$ acetylsalicylic acid, BID = twice daily, PED = Pipeline embolization device, PRU = platelet reactivity unit.

\section{Table 3. Outcomes for Patients Receiving Ticagrelor and ASA after PED Placement}

\begin{tabular}{|c|c|}
\hline Outcome & $\begin{array}{l}\text { No. (\%) of Patients* } \\
(n=29)\end{array}$ \\
\hline Ischemic stroke or death within 1 year & $4(14)$ \\
\hline $\begin{array}{l}\text { Intracerebral hemorrhagic complications } \\
\text { within } 1 \text { year }\end{array}$ & $0 \quad(0)$ \\
\hline $\begin{array}{l}\text { Platelet function testing } \\
\text { (after initiation of ticagrelor) }\end{array}$ & \\
\hline Platelet function tested & $28 \quad(97)$ \\
\hline $\begin{array}{l}\text { No. of PRU measurements per patient } \\
(\text { mean } \pm \text { SD) }\end{array}$ & $2.1 \pm 1$ \\
\hline PRU value (mean \pm SD) & $65 \pm 57$ \\
\hline
\end{tabular}

ASA = acetylsalicylic acid, PED = Pipeline embolization device, $\mathrm{PRU}=$ platelet reactivity unit, $\mathrm{SD}=$ standard deviation .

*Except where indicated otherwise.

Overall, these findings are similar to those of another small, single-centre study. In their analysis comparing ticagrelor and clopidogrel therapy in 103 patients who underwent flow diverter placement for aneurysm, Moore and others ${ }^{3}$ concluded that ticagrelor was safe and effective for prevention of thromboembolic complications. Similar to the study reported here, they did not observe any cases of intracranial hemorrhage during follow-up. Thrombotic complications occurred in $4.2 \%$ of patients in their ticagrelor cohort, similar to the observed thromboembolic complication rate of $3 \%$ in the current study. The average post-procedure follow-up period in the study by Moore and others ${ }^{3}$ was 7.6 and 7.2 months in the clopidogrel and ticagrelor groups, respectively. Our study adds to knowledge about the utility of ticagrelor after PED placement by extending follow-up to 12 months after the procedure, by describing PRU data for all but one of the patients, and by including 11 patients whose dosage of ticagrelor was reduced to $60 \mathrm{mg}$ twice daily (Table 2).

The interest in ticagrelor for patients who have undergone some form of neurointervention is largely attributed to the reported rate of nonresponse or hyporesponse to clopidogrel, which may be as high as $20 \%$ to $30 \%{ }^{4-6}$ Furthermore, Adeeb and others ${ }^{9}$ reported an alarming thrombotic complication rate in patients with nonresponse to clopidogrel, relative to those with response to clopidogrel, after PED placement $(17.4 \%$ versus $5.6 \% ; p<0.01)$. At our institution, the use of ticagrelor after PED placement became the standard because of escalating concern about clopidogrel nonresponse and a desire to standardize care. Given the lack of robust clinical trials describing ticagrelor for this patient population, we continued to evaluate PRU levels in many of these patients, in an effort to assess bleeding risk and detect 
opportunities to utilize a 60-mg twice daily dosing strategy (Table 2). This case series highlights a potential management strategy in the setting of highly variable practice in the United States, where it has been reported that up to $58 \%$ of facilities may not use ticagrelor, even for patients with nonresponse to clopidogrel. ${ }^{10}$

The PRU results for the patients in this case series prompt additional considerations for the clinician, since none of these patients would have met the criteria for "nonresponse". ${ }^{11,12}$ Although a PRU range of 70 to 150 has been suggested as optimal to reduce hemorrhagic and thromboembolic complications, ${ }^{7}$ the mean PRU value after ticagrelor administration was below this suggested range (65 [SD 57]). Indeed, the mean PRU value reported here implies that a portion of the values were below 60 , a threshold that has been statistically associated with hemorrhagic complications after PED placement.' However, we did not observe any cases of intracranial hemorrhage in this patient population, despite some PRU values being less than this previously described target threshold. The absence of intracranial hemorrhage in this case series leads to additional consideration of whether PRU testing in these patients is valuable, and if so, what dosage of ticagrelor should be utilized at a defined PRU threshold. The neurointerventionalists at the study institution appreciated this risk and were able to reduce the dose of ticagrelor to $60 \mathrm{mg}$ 2 times per day if the PRU was considered low and/or the patient was experiencing any minor bleeding.

This study had some limitations. Although we were able to describe patient scenarios that are common to hospitals where PED placement is performed, ours was a single-centre study with small sample size, which limits its generalizability. We cannot confirm any relation between our antiplatelet strategy and safety or efficacy outcomes. Data collection was performed retrospectively and depended on the accuracy and completeness of chart documentation. Although EMRs are integrated across 23 hospitals in our region of the United States, we cannot exclude the possibility that safety outcomes in some patients were managed by an outside facility. Finally, we did not assess certain common adverse effects of this medication combination, such as gastrointestinal bleeding.

\section{CONCLUSION}

In this case series describing the use of ticagrelor and ASA as dual antiplatelet therapy after PED placement for cerebral aneurysm, only one ischemic event was observed during the 1-year follow up, and this event occurred after dual antiplatelet therapy had been discontinued. No intracranial hemorrhage events were observed. Further prospective trials are needed to describe the utility of ticagrelor use after PED placement, as well as its dosing and monitoring.

\section{References}

1. Brouillard AM, Sun X, Siddiqui AH, Lin N. The use of flow diversion for the treatment of intracranial aneurysms: expansion of indications. Cureus. 2016;8(1):e472.
2. Levine GN, Bates ER, Bittl JA, Brindis RG, Fihn SD, Fleisher LA, et al. 2016 ACC/AHA guideline focused update on duration of dual antiplatelet therapy in patients with coronary artery disease: a report of the American College of Cardiology/American Heart Association Task Force on Clinical Practice Guidelines: an update of the 2011 ACCF/AHA/SCAI guideline for percutaneous coronary intervention, $2011 \mathrm{ACCF} / \mathrm{AHA}$ guideline for coronary artery bypass graft surgery, 2012 ACC/AHA/ACP/AATS/ PCNA/SCAI/STS guideline for the diagnosis and management of patients with stable ischemic heart disease, 2013 ACCF/AHA guideline for the management of ST-elevation myocardial infarction, 2014 ACC/AHA guideline for the management of patients with non-ST-elevation acute coronary syndromes, and 2014 ACC/AHA guideline on perioperative cardiovascular evaluation and management of patients undergoing noncardiac surgery. J Am Coll Cardiol. 2016;68(10):1082-115.

3. Moore JM, Adeeb N, Shallwani H, Gupta R, Patel AS, Griessenauer CJ, et al. A multicenter cohort comparison study of the safety, efficacy, and cost of ticagrelor compared to clopidogrel in aneurysm flow diverter procedures. Neurosurgery. 2017;81(4):665-71.

4. Delgado Almandoz JE, Crandall BM, Scholz JM, Fease JL, Anderson RE, Kadkhodayan Y, et al. Last-recorded P2Y12 reaction units value is strongly associated with thromboembolic and hemorrhagic complications occurring up to 6 months after treatment in patients with cerebral aneurysms treated with the pipeline embolization device. AJNR Am J Neuroradiol. 2014; 35(1):128-35.

5. Nordeen JD, Patel AV, Darracott RM, Johns GS, Taussky P, Tawk RG, et al. Clopidogrel resistance by P2Y12 platelet function testing in patients undergoing neuroendovascular procedures: incidence of ischemic and hemorrhagic complications. J Vasc Interv Neurol. 2013;6(1):26-34.

6. Yang H, Li Y, Jiang Y. Insufficient platelet inhibition and thromboembolic complications in patients with intracranial aneurysms after stent placement. J Neurosurg. 2016;125(2):247-53.

7. Daou B, Starke RM, Chalouhi N, Barros G, Tjoumakaris S, Rosenwasser $\mathrm{RH}$, et al. P2Y12 reaction units: effect on hemorrhagic and thromboembolic complications in patients with cerebral aneurysms treated with the pipeline embolization device. Neurosurgery. 2016;78(1):2733.

8. Derdeyn CP, Chimowitz MI, Lynn MJ, Fiorella D, Turan TN, Janis LS, et al. Aggressive medical treatment with or without stenting in high-risk patients with intracranial artery stenosis (SAMMPRIS): the final results of a randomized trial. Lancet. 2014;383(9914):333-41.

9. Adeeb N, Griessenauer CJ, Foreman PM, Moore JM, Shallwani H, Motiei-Langroudi R, et al. Use of platelet function testing before Pipeline embolization device placement: a multicenter cohort study. Stroke. 2017; 48(5):1322-30.

10. Gupta R, Moore JM, Griessenauer CJ, Adeeb N, Patel AS, Youn R, et al. Assessment of dual-antiplatelet regimen for Pipeline embolization device placement: a survey of major academic neurovascular centers in the United States. World Neurosurg. 2016;96:285-92.

11. Gurbel PA, Bliden KP. Interpretation of platelet inhibition by clopidogrel and the effect of non-responders. J Thromb Haemost. 2003;1(6):1318-9.

12. Müller I, Besta F, Schulz C, Massberg S, Schönig A, Gawaz M. Prevalence of clopidogrel non-responders among patients with stable angina pectoris scheduled for elective coronary stent placement. Thromb Haemost. 2003; 89(5):783-78.

Jodi R DeGrote, PharmD, BCCCP, is with Pharmacy Services, Sanford Medical Center, Fargo, North Dakota.

Elizabeth M Olafson, PharmD, is with Pharmacy Services, Sanford Medical Center, Fargo, North Dakota.

Alexander Drofa, MD, is with the Department of Surgery, University of North Dakota, Grand Forks, North Dakota, and the Department of Neurosurgery, Sanford Brain and Spine Institute, Fargo, North Dakota. 
Evgueni Kouznetzov, MD, is with the Department of Neurosurgery, Sanford Brain and Spine Institute, Fargo, North Dakota.

Michael Manchak, MD, is with the Department of Neurosurgery, Sanford Brain and Spine Institute, Fargo, North Dakota.

Nathan D Leedahl, PharmD, BCPS, is with Pharmacy Services, Sanford Medical Center, Fargo, North Dakota.

David D Leedahl, PharmD, BCPS-AQ ID, BCCCP, is with Pharmacy Services, Sanford Medical Center, Fargo, North Dakota.

Competing interests: Alexander Drofa has received personal consulting fees from Medtronic and Microvention, for activities outside the work reported here. No other competing interests were declared.
Address correspondence to:

Dr David D Leedahl

Sanford Medical Center

801 Broadway North

Fargo ND 58122 USA

e-mail: David.Leedah|@SanfordHealth.org

Funding: Discretionary funds for the statistical analysis were provided by Sanford Pharmacy Services.

\section{ON THE FRONT COVER}

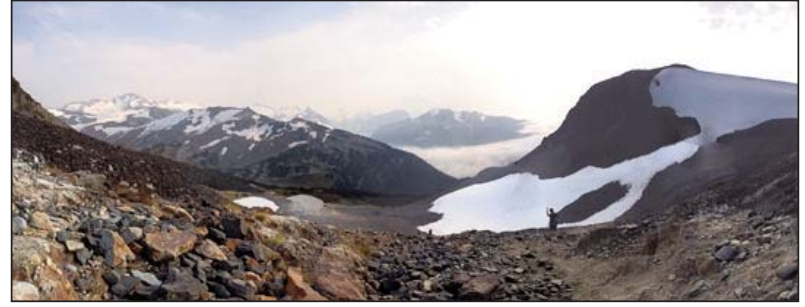

The CJHP would be pleased to consider photographs featuring Canadian scenery taken by CSHP members for use on the front cover of the Journal. If you would like to submit a photograph, please send

\section{Garibaldi Provincial Park British Columbia}

The photograph on this issue's front cover was taken by Yvonne Huang while she was hiking up the rubble en route to the Black Tusk in Garibaldi Provincial Park. Yvonne is a Clinical Pharmacist at Surrey Memorial Hospital in Surrey, British Columbia. She used her iPhone to capture the image.

an electronic copy (minimum resolution $300 \mathrm{dpi}$ ) to publications@cshp.ca. 